\title{
The Influence of Self-Determination, Organizational Culture, Work Motivation, and Job Satisfaction on the Performance of Principals of State Primary School in Aceh Besar District, Aceh
}

\author{
Hambali ${ }^{12 a *}$, Zainuddin ${ }^{2 b}$, \& Darwin $2, c$ \\ 1Department of Primary School Teacher Education, Serambi Mekkah University, Banda Aceh, Indonesia \\ 2Postgraduate Doctoral in Educational Management, State University of Medan, Medan, Indonesia \\ a hambali@serambimekkah.ac.id ; b zaindjaros1955@gmail.com; c darwinspi@unimed.ac.id \\ *Corresponding Author: hambali@serambimekkah.ac.id | Phone : +6281360889491
}

\begin{abstract}
The performance of the principal of SD Negeri is the positive or negative behavior of the principal of SD in achieving SD goals. This study found that: (1) self-determination affects the work motivation of primary school principals by $25.3 \%$; (2) organizational culture affects the work motivation of primary school heads in Aceh Besar District by $27.9 \%$; (3) self-determination affects the job satisfaction of primary school principals in Aceh Besar District by 27.1\%; (4) organizational culture affects the job satisfaction of primary school principals in Aceh Besar District by 21.5\%; (5) selfdetermination affects the performance of primary school principals in Aceh Besar District by 20.2\%; (6) organizational culture affects the performance of primary school principals in Aceh Besar District by 17.5\%; (7) work motivation affects the performance of primary school principals in Aceh Besar District by $18.9 \%$, and (8) job satisfaction affects the performance of primary school principals in Aceh Besar District by $24.5 \%$. Based on the results of the study, it found that self-determination, organizational culture, work motivation, and job satisfaction had a positive and significant effect on the performance of the principal of SD Negeri in Aceh Besar District, Aceh Province.
\end{abstract}

Keywords: self-determination; organizational culture; work motivation; job satisfaction; principal performance

\section{Introduction}

Schools as part of the education system must be able to position themselves as an institution that is not just a gathering place for teachers and students but must be designed to be an institution capable of acting as agents of change and custodians of cultural values. To realize this, the school as an educational institution requires a leader or principal who can empower the institution's existing resources. The principal is very instrumental in moving the school's various components so that the teaching and learning process at the school runs well. According to Sujanto (2018: 34), ideally, the principal of an elementary school has a strong desire to succeed in achieving the vision, mission, and goals of elementary education. Also, the principal of an elementary school must always use persuasive techniques to influence teachers and education personnel's thoughts and actions in carrying out tasks beyond expected. Primary school principals perform managerial, entrepreneurial and supervisory tasks without the supervision of others. The SD principal always creates a trusting relationship between the teacher, education staff, and the principal of the SD so that it can lead to the belief that each party will provide benefits for both. With a good performance in elementary education organizations, communication will run smoothly, and all work becomes easy to complete. However, in reality, these ideal conditions have not been seen empirically in the field. The principal of SD does not have a strong desire to achieve the vision, mission, and goals of SD education. Besides, elementary school principals do not use persuasive techniques to influence others' thoughts and actions in carrying out tasks beyond expected.

Primary school principals have not been able to fully carry out managerial, entrepreneurial, and supervisory duties without others' supervision. The fact is on results of the pre-survey shows that the Principal of SD as follows: (1) has not fully compiled SD planning properly; (2) have not thoroughly carried out their duties without the supervision of others to realize effective learning; (3) not yet entirely leading SD in the context of optimizing the utilization of school human resources; (4) have not altogether had a strong desire to work hard until they succeed in realizing the vision, mission and goals of elementary school 
education; (5) have not fully managed teachers and staff in order to optimize human resource utilization; (6) has not entirely managed the school relationship with the community in order to seek support for ideas, learning resources, and school funding; (7) have not fully worked hard to achieve the success of the school as a practical learning organization; (8) has not entirely managed the school's select service units in supporting learning activities and student activities in schools; (9) not yet fully utilizing advances in information technology for improving learning and school management; (10) not yet fully entrepreneurial in managing school activities as a learning resource for students; (11) has not thoroughly planned the supervision, monitoring, evaluation and follow-up planning; (12) lack of establishing a trusting relationship between teachers, education staff and primary school principals so as to create confidence that each party will provide benefits for both; and (13) lack of using effective techniques to influence the thoughts and actions of others in performing tasks beyond what is expected.

Data from the Aceh Besar District Education Office, from 203 SD units, were mostly led by school principals with backgrounds outside primary school teacher education (PGSD). The results of monitoring and data collection from the Aceh Besar District Education Office are about 20\% (43 people) of school principals who have an educational background for primary school teachers, around $70 \%$ have educational experiences outside PGSD (graduates of S1 Mathematics, S1 Indonesian Language, S1 Sports, and others. ). Of the 203 people, only 12 of them have a bachelor's degree in education. Even then, they do not have a Masters in Basic Education. This situation shows that the principal of SD in Aceh Besar District skillfully cannot manage learning administration at the SD level. It shows that the performance offered by the SD principal is still far from satisfactory.

Regulation of the Minister of National Education Number 28 the Year 2010, Chapter I General Provisions, Article 1, states that the principal is a teacher given an additional task to lead the school. In line with the increasing demands of the community for school accountability, so are the demands for school principals' performance. Principals are expected to carry out their primary duties and functions as managers and leaders. As the education leader in the school, the principal has full responsibility for developing all school resources. The principal's leadership effectiveness depends on the ability to work with all school members and his ability to control school management to create a teaching and learning process. The approach used in this research is the development of a performance model. This model's comparison is from the variables that affect both differences, contradictions, and the extent of the model's scope in explaining performance. These analysis results expect to find a new model that can explain performance in a comprehensive, relevant, contextual and competitive manner as a model for developing human resources, especially primary school principals. Colquitt, LePine and Wesson (2015: 98) in their model to achieve performance will be influenced by organizational factors (such as culture and organizational structure), group behavior and leadership mechanism factors, leadership influence and power, process and group characteristics (team), and individual characteristics (organizational culture and cultural values, and abilities) and these variables can also affect job satisfaction, stress, motivation, and learning so that ultimately will affect performance. Gary and Edwin (2009: 79) that performance is a factor that is influenced by individual abilities and characteristics and the presence of organizational support. In line with Melvin and Charles in Schermerhorn, Hunt, and Osbornt (2015: 76), who determine performance consists of three dimensions that are interrelated to produce performance, namely individual attributes, wok effort, and organization support, which means that individual attributes are related to capacity owned by individuals to work, characteristics of the ability to work such as values, attitudes, and organizational culture (wok effort) and characteristics related to organizational support and opportunities for work such as workgroup dynamics, organizational size, organizational structure, and technology, resources power, purpose and leadership. Porter and Lawler stated by Mullins (2015: 28) that the results of perceived effort and value of reward together affect individual effort in realizing their performance. Self-characteristics and abilities, and perceptions of roles and opportunities jointly within the organization affect organizational performance.

Summary of data obtained from the Aceh Besar District Education Office for 2019/2020, the number of SD is 203 units. The highest diploma obtained is 15 heads of PGSD graduates, 188 people from S1 teacher training, of which only eight people have master teacher certificates. The results of monitoring by the Aceh Besar District Education Office show that the principal of SD is still lacking in carrying out their duties and responsibilities as an SD head. Only about 50\% can carry out their duties and responsibilities properly at school. The reason for the primary school principal, among others, is to meet family income. It makes less motivated and unable to fully manage the time for the development of the SD they lead; in turn, the tasks and responsibilities that should maximally not properly, so that SD head performance is not good. The description above explains the various factors that affect performance, both from research results and theoretical explanations. If not resolved immediately, it will affect the achievement of the primary school principal's performance, which will affect the organization's performance so that it will have an impact on improving the quality of education in Aceh Province. Therefore, in a theoretical model and overcome the 
head of the SD Negeri's performance problems, it is necessary to research the influence of self-determination, organizational culture, work motivation, and job satisfaction on the performance of the principal of SD Negeri in Aceh Besar District, Aceh Province.

\section{Methods}

The type used in this research is quantitative research with ex post facto research. Kerlinger (2015: 188) clarifies that non-experimental researchers are systematic empirical studies in which the scientist cannot directly control the independent variables because their manifestations have appeared or because the nature of the variables covers the possibility of manipulation. Analyze one variable with other variables; path analysis is used. The population in this study were 203 primary school heads in Aceh Besar District, Aceh Province. While the sampling technique uses the formula from Slovin in Riduwan (2012: 49) with the procedure: Information: $\mathrm{n}=$ Sample size $\mathrm{N}=$ population $\mathrm{d}=$ Degree of error Based on the Slovin formula, for a population of $\mathrm{N}=176$, and the degree of error $\mathrm{d}$ of 0.05 , the number of samples is obtained: $\mathrm{n}=$ Based on the formula above, the number of research samples is 153 principals.

\section{Results and Discussion}

\subsection{Results}

\section{Test the normality of data; the One-Sample Kolmogorov}

Smirnov Test formula is to use. The hypothesis proposed is: Ho: the data comes from a normally distributed population Ha: data do not come from populations with normal distribution To determine whether the research data is standard or not, done by comparing the absolute most significant difference or the highest value (Dhitung) with the Dtabel value and the Asymp value. Sig (2-tailed) at the significance level $\alpha=0.050$ with the following conditions:

- If the significance obtained is $>a$, then the data comes from a normally distributed population.

- If the value obtained is $<\alpha$, then the data do not come from a normally distributed community.

Based on the normality test calculation, a summary of the results of testing the normality of data from each research variable was obtained, as shown in Table 1. Based on the summary of the calculation results in Table 1 above, it shows that the Asymp. Sig. (2-tailed) $>0.05$ for all variables, so it can conclude that the distribution of data on self-determination (X1), organizational culture (X2), work motivation (X3), job satisfaction (X4), and the performance of primary school principals (X5) customarily distributed, thus the assumption of normality has been fulfilled.

1. Test of Linearity and Meaning of the Regression Equation To test the linearity assumption, it was carried out based on the linearity test with the F test on each endogenous variable's data on the exogenous variable. The hypothesis proposed in the linearity test is:

Ho; regression is not linear Ha: linear regression Testing criteria: reject Ho if the significance of Fcount $>$ 0.050 or accept Ho if the importance of Fount $<0.050$. Test the regression equation; the proposed hypothesis is Ho: regression is not significant Ha: significant deterioration The test criteria: reject Ho if the significance value of Fcount $>0.050$ or accept Ho if the significance of the value Fcount $<0.050$. The summary of the results of the linearity test and the regression equation significance test using SPSS Ver. 23 for windows for each pair of exogenous variables with endogenous variables presented in the Table 2 .

Based on the test criteria above, where for the linearity test, the significance of the F value must be greater than 0.050 and for the regression significance test, the significance of the $\mathrm{F}$ value must be less than 0.050 , so the relationship between the exogenous variable and the endogenous variable is linear. Based on

Table 2. it concluded as follows:

1). The relationship between self-determination (X1) and work motivation (X3) is obtained: for the linearity test, the significance of the Fh value of 0.077 is more significant than 0.050 , and for the regression significance test, the significance of the Fh value of 0.001 is less than 0.050 thus the relationship of selfdetermination (X1) with work motivation (X3) is linear and meaningful (see No.1 Table 2).

2) The relationship between organizational culture $(X 2)$ and work motivation (X3) is obtained: for the linearity test, the significance of the Fh value of 0.498 is greater than 0.050 and for the regression significance test, the significance of the Fh value of 0.000 is less than 0.050 thus the relationship of organizational culture (X2) with work motivation (X3) is linear and meaningful (see No.2 Table 2).

3) The relationship between self-determination (X1) and job satisfaction (X4) is obtained: for the linearity 
test, the significance of the Fh value of 0.626 is more significant than 0.050 , and for the regression significance test, the significance of the Fh value of 0.000 is less than 0.050 thus the relationship of selfdetermination (X1) with job satisfaction (X4) is linear and meaningful (see No. 3 Table 2).

4) The relationship between organizational culture (X2) and job satisfaction (X4) is obtained: for the linearity test, the significance of the Fh value of 0.262 is more generous than 0.050 , and for the regression significance test, the significance of the Fh value of 0.003 is less than 0.050 thus the relationship of organizational culture (X2) with job satisfaction (X4) is linear and meaningful (see No. 4 Table 2).

5) The test obtained the relationship between self-determination (X1) and the principal's performance (X5) for the linearity test; the significance of the Fh value of 0.761 is more remarkable than 0.050 . For the regression significance test, the importance of the Fh value of 0.000 is less than 0.050 ; thus, the relationship of self-determination (X1) with the performance of the SD head (X5) is linear and meaningful (see no.5 Table 2).

6) The relationship between organizational culture (X2) and the principal's performance (X5) obtained for the linearity test, the significance of the Fh value of 0.091 , was more extraordinary than 0.050 . For the regression significance test, the significance of the Fh value of 0.000 was less than 0.050 ; thus the relationship between organizational culture (X2) with the performance of the SD head (X5) is linear and meaningful (see no 6 Table 2).

7) The relationship between work motivation (X3) and the principal's performance (X5) obtained for the linearity test, the significance of the Fh value of 0.122 , is more significant than 0.050 . For the regression significance test, the significance of the Fh value of 0.000 is less than 0.050 ; thus, the relationship of work motivation (X3) with the SD head performance (X5) is linear and meaningful (see no 7 Table 2).

8) The relationship between job satisfaction (X4) and the principal's performance (X5) obtained for the linearity test, the significance of the Fh value of 0.201 , is more generous than 0.050 . For the regression significance test, the importance of the Fh value of 0.000 is less than 0.050 ; thus, the relationship of work motivation (X4) with the SD head performance (X5) is linear and meaningful (see No. 8 Table 2). A.

Table 1. Summary of the Kolmogorov-Smirnov Test Normality Calculation One-Sample Kolmogorov-Smirnov Test

\begin{tabular}{|c|c|c|c|c|c|c|}
\hline & & $\begin{array}{c}\text { Self- } \\
\text { Determination }\end{array}$ & $\begin{array}{c}\text { Organizational } \\
\text { Culture }\end{array}$ & $\begin{array}{c}\text { Work } \\
\text { Motivation }\end{array}$ & $\begin{array}{c}\text { Work } \\
\text { satisfaction }\end{array}$ & $\begin{array}{c}\text { Principal } \\
\text { Performance }\end{array}$ \\
\hline $\mathrm{N}$ & & 135 & 135 & 135 & 135 & 135 \\
\hline \multirow[t]{2}{*}{ Normal Parameters ${ }^{\mathrm{a}, \mathrm{b}}$} & Mean & 88,67 & 80,89 & 98,56 & 112,49 & 139,39 \\
\hline & Std. Deviation & 15,325 & 20,945 & 16,893 & 21,336 & 24,016 \\
\hline M ost Extreme & Absolute & ,047 & ,059 & ,067 & ,072 & ,068 \\
\hline \multirow[t]{2}{*}{ Differences } & $\begin{array}{ll}\mathrm{P} & \text { Positive } \\
\end{array}$ & 047 & 055 & ,038 & 056 &, 054 \\
\hline & $\mathrm{N}$ gNegative &,- 047 &,- 059 &,- 067 &,- 072 &,- 068 \\
\hline Test Statistic & & ,047 & 059 & ,067 & 072 & 068 \\
\hline Asymp. Sig. (2-tailed) & & ,200c,d & $200^{c, d}$ & $200^{\mathrm{c}, \mathrm{d}}$ & $082^{\mathrm{c}}$ & ,200 c,d \\
\hline
\end{tabular}

Table 2. Summary of Linearity Test Results and Significance Test

\begin{tabular}{|c|c|c|c|c|c|c|c|}
\hline \multirow{2}{*}{ No. } & \multirow{2}{*}{ Variable } & \multicolumn{3}{|c|}{ Test of Linearity } & \multicolumn{3}{|c|}{ Test of Significance of Regression } \\
\hline & & $F_{h}$ & Sig. & Status & $\mathbf{F}_{\mathrm{h}}$ & Sig. & Status \\
\hline 1 & $\mathrm{X}_{1}$ with $\mathrm{X}_{3}$ & 1,433 & 0,077 & Linear & 12,123 & 0,001 & Significant \\
\hline 2 & $\mathrm{X}_{2}$ with $\mathrm{X}_{3}$ & 0,990 & 0,498 & Linier & 14,312 & 0,000 & Significant \\
\hline 3 & $\mathrm{X}_{1}$ with $\mathrm{X}_{4}$ & 0,912 & 0,626 & Linier & 13,051 & 0,000 & Significant \\
\hline 4 & $\mathrm{X}_{2}$ with $\mathrm{X}_{4}$ & 1,176 & 0,262 & Linier & 8,850 & 0,003 & Significant \\
\hline 5 & $\mathrm{X}_{1}$ with $\mathrm{X}_{5}$ & 0,822 & 0,761 & Linear & 18,855 & 0,000 & Significant \\
\hline 6 & $\mathrm{X}_{2}$ with $\mathrm{X}_{5}$ & 1,418 & 0,091 & Linear & 15,292 & 0,000 & Significant \\
\hline 7 & $\mathrm{X}_{3}$ with $\mathrm{X}_{5}$ & 1,338 & 0,122 & Linear & 16,875 & 0,000 & Significant \\
\hline 8 & $\mathrm{X}_{4}$ with $\mathrm{X}_{5}$ & 1,227 & 0,201 & Linear & 21,814 & 0,000 & Significant \\
\hline
\end{tabular}

\subsection{Discussion}

Based on data descriptions and hypothesis testing, the following discussion. 1. Self-determination has a positive direct effect on work motivation The findings of the first study: self-determination has an immediate positive impact on work motivation, meaning that if self-determination is getting better, work motivation will also be higher. The distribution of self-determination data shows 18 people $(13.333 \%)$ in the high category, 83 people $(61.481 \%)$ in the moderate category, 31 people $(22.963 \%)$ in the low class, and three people $(2.222 \%)$ in the low sort. Overall, it can conclude that the self-determination of the SD Negeri Heads in Aceh Besar District tends to be in the medium category. 
Based on hypothesis testing, the path coefficient $\rho 31=0.253$ and $t=3.148$ with a significance level of 0.002 (the hypothesis is accepted if the significance level of the count $<0.050$ ). Furthermore, based on the calculation results, the total direct effect of self-determination on work motivation is 0.289 . It shows that $28.9 \%$ of work motivation changes can determine with self-determination. From the study results, we conclude that self-determination influenced the work motivation of the principal of SD Negeri in Aceh Besar District. This study's results are in line with the theory proposed by Robbins and Coulter (2018: 138), which states that self-determination directly affects one's work motivation. When self-determination is high, the person's motivation to achieve goals will be even higher. The research results obtained also support research conducted by Gagné and Edward (2005: 331); Yohanes et al. (2019: 229); Niyomsin (2018: 114); Van den Broeck et al. (2016: 1195); and research by Arshadi (2010: 1267) that self-determination has a significant effect on work motivation. Thus, it concluded that to increase a person's work motivation can be done by optimizing that person's determination. In this study, self-determination variables are on indicators: (a) able to direct their knowledge, effort, and attention, (b) can increase their persistence, (c) have alternative problem solving, (d) be able to control themselves, (e) like to work hard, and (f) acknowledging the contribution of others in achieving organizational goals. We found that the indicator can increase persistence as a dominant indicator in increasing one's self-determination from further calculations. Thus, we can state that to improve one's self-determination, we can optimize indicators that can increase persistence. Elementary school principals who have high self-determination will see obstacles in working as a challenge to success. Elementary school principals who have high self-determination will not see obstacles in carrying out their duties as obstacles to failure, but will try to exert their knowledge, efforts, and attention and increase their work persistence to succeed in carrying out their duties. When the SD principal can achieve continuous success, the SD principal's support will increase. Thus it can be stated that self-determination affects the work motivation of the principal of SD Negeri in Aceh Besar District. In other words, the principal of SD Negeri in Aceh Besar District can increase the work motivation of the principal of SD Negeri through optimizing the self-determination they have. Thus, this study's findings state that self-determination has a positive direct effect on work motivation according to the research results and the theory referred to in the study. 1. Organizational Culture Has a Positive Direct Effect on Work Motivation The second research finding: organizational culture has a positive direct effect on work motivation, meaning that if the organizational culture is getting better, the work motivation will also be higher. The distribution of corporate culture data shows 28 people $(20.741 \%)$ in the high category, 50 people $(37.037 \%)$ in the moderate category, 43 people $(31.852 \%)$ in the low category, and 14 people $(10.370 \%)$ in the low category. Overall, we can conclude that the organizational culture of the head of SD Negeri in Aceh Besar District tends to be in the medium category.

Coefficient of $\rho 32=0.279, t=3.472$ with a significance level of 0.001 (the hypothesis is accepted if the significance level of the count $<0.050$ ). Furthermore, based on the calculation results, the total direct effect of organizational culture on work motivation is 0.312 . It shows that $31.2 \%$ of changes in work motivation can determine by organizational culture. From the study results, we concluded that organizational culture influenced the work motivation of the principal of SD Negeri in Aceh Besar District. This study's results are in line with the theory proposed by Robbins and Coulter (2018: 138), which states that organizational culture directly affects a person's work motivation. If the organizational culture is high, then the person's motivation to achieve goals will be even higher. The research results obtained also support the research conducted by Yusof et al. (2016: 50); Weerasinghe (2017: 59); Maithel, Chaubey, and Deepak (2012: 68); and research by Nawawi et al. (2018: 11) that organizational culture has a significant effect on work motivation.

Thus it can be concluded that to increase one's work motivation can be done by optimizing organizational culture. In this study, organizational culture variables are on indicators: (a) individual initiative, (b) tolerance for risky actions, (c) support and direction from superiors, (d) control, (e) a clear reward system, ( $\mathrm{f}$ ) tolerance of conflict, and (g) good communication with superiors and subordinates. From the results of further calculations, we found that the indicators of support and direction from superiors are dominant indicators in providing a correlation for improving organizational culture. Thus, it can state that improving organizational culture can be done by optimizing support and direction from superiors. 1. Selfdetermination has a positive direct effect on job satisfaction The third research finding: self-determination has a positive direct effect on job satisfaction, meaning that if self-determination is getting better, job satisfaction will also be higher. The distribution of self-determination data shows 18 people $(13.333 \%)$ in the high category, 83 people $(61.481 \%)$ in the moderate category, 31 people $(22.963 \%)$ in the low category, and three people $(2.222 \%)$ in the low category. Overall, we can conclude that the self-determination of the SD Negeri Heads in Aceh Besar District tends to be in the medium category. Based on hypothesis testing with the path coefficient $\rho 41=0.271$ and $t=3.324$ with a significance level of 0.001 (the hypothesis is accepted if the $t$-count $<0.050$ ) is accepted. Furthermore, based on the calculation results, the total direct effect of selfdetermination on job satisfaction is 0.299 . shows that $29.9 \%$ of changes in job satisfaction can determine by 
self-determination. From the study results, we conclude that self-determination influenced the work motivation of the principal of SD Negeri in Aceh Besar District. This study's results are in line with the theory proposed by Robbins and Coulter (2018: 138), which states that self-determination directly affects one's job satisfaction. When self-determination is high, the person's motivation to achieve their goals will be even higher. The research results obtained also support research conducted by Shafique, Masood, and Bashir (2018); Iqbal, Anwar, and Haider (2015); Thompson and Jon (2016); and Rathore et al. (2017) which state that self-determination has a significant effect on work motivation. Thus, we can conclude that to increase one's job satisfaction can be done by optimizing that person's self-determination. In this study, self-determination variables are on indicators: (a) able to direct their knowledge, effort, and attention, (b) can increase their persistence, (c) have alternative problem solving, (d) be able to control themselves, (e) like to work hard, and (f) acknowledging the contribution of others in achieving organizational goals. From the results of further calculations, we found that the indicator can increase persistence as a dominant indicator in providing a correlation to increase one's self-determination. Thus, it can state that improving one's self-determination can be done by optimizing indicators that can increase persistence. 2. Organizational Culture Has a Positive Direct Effect on Job Satisfaction The fourth research finding: organizational culture has a positive direct effect on job satisfaction, meaning that if the organizational culture is getting stronger, then job satisfaction will also be higher. The distribution of corporate culture data shows 28 people $(20.741 \%)$ in the high category, 50 people $(37.037 \%)$ in the moderate category, 43 people $(31.852 \%)$ in the low category, and 14 people $(10.370 \%)$ in the low category. Overall, we can conclude that the head of SD Negeri in the Aceh Besar District tends to be in the medium category. Based on hypothesis testing, the path coefficient $=0.215$ and $t=$ 2.633 with a significance level of 0.009 (the hypothesis is accepted if the $t$-count $<0.050$ ) is accepted. Furthermore, based on the calculation results obtained, organizational culture's direct effect on job satisfaction of 0.250 . Thus, organizational culture positively affects job satisfaction, where $25 \%$ of job satisfaction changes can determine by organizational culture.

Based on the study results, we conclude that organizational culture affects the job satisfaction of the head of SD Negeri in Aceh Besar District. This study's results are in line with the theory proposed by Robbins and Coulter (2018: 138), which states that organizational culture directly affects one's job satisfaction (Kristiani et al, 2019; Manaf et al, 2019; Rajindra et al, 2020). If the organizational culture is high, the job satisfaction of the person will be higher (Ridlo et al, 2020; Simorangkir et al, 2019). The results obtained also support the research conducted by Habib et al. (2014: 215); Vukonjanski and Milan (2013); Siagian \& Sirait (2019), Musifudin et al, (2019), Hanjarini et al, (2020) and research by Qazi, Mohammad, and Pretty (2017: 215) that organizational culture has a significant effect on job satisfaction. Thus it can be concluded that to increase one's job satisfaction can be done by optimizing organizational culture. In this study, organizational culture variables are on indicators: (a) individual initiative, (b) tolerance for risky actions, (c) support and direction from superiors, (d) control, (e) a transparent reward system, ( f) tolerance of conflict, and (g) good communication with superiors and subordinates. The results of further calculations found that the indicators of support and direction from superiors are dominant indicators in providing a correlation for improving organizational culture. Thus, it can state that improving organizational culture can be done by optimizing support and direction from superiors. When a principal who has high self-determination achieves success, the principal does not overestimate his success and respect others' contributions who have supported his success because one of the indicators of a principal who has high self-determination is having humility.

Humility involves the ability to evaluate success, job failures, and life without overdoing it. Thus, this study's findings, which state that organizational culture directly has a significant positive effect on job satisfaction, are following the results of the research and the theory referred to in this study. 1 . Selfdetermination has a positive direct effect on the performance of the principal of public elementary schools The findings of the fifth study: self-determination has a positive direct effect on the performance of the head of public elementary schools, meaning that if self-determination is getting better, the performance of the primary school principal will also be more robust. Data on self-determination shows that 18 people $(13.333 \%)$ are in the high category, 83 people $(61.481 \%)$ in the medium category, 31 people $(22.963 \%)$ in the low category, and three people $(2.222 \%)$ in the low category. Overall, it can conclude that the selfdetermination of the SD Negeri Heads in Aceh Besar District tends to be in the medium category. The study results concluded that self-determination influenced the work motivation of the principal of SD Negeri in Aceh Besar District. This study's results are in line with the theory proposed by Latham and Locke (2009: 79), which states that self-determination directly affects one's performance. When self-determination is high, the person's motivation to achieve their goals will be even higher. The results obtained also support research conducted by Basit, Veronica and Zubair (2017: 112); Ekaningsih (2014); Mehrabi et al. (2012); and Pradeep and Prabhu (2011), which state that self-determination has a significant effect on work motivation. Thus, it can conclude that improving one's performance can be done by optimizing that person's determination. In this study, self-determination variables are on indicators: (a) able to direct their knowledge, effort, and 
attention, (b) can increase their persistence, (c) have alternative problem solving, (d) be able to control themselves, (e) like to work hard, and (f) acknowledging the contribution of others in achieving organizational goals. The results of further calculations found that the indicator can increase persistence as a dominant indicator in providing a correlation to increase one's self-determination. Thus, it can state that improving one's self-determination can be done by optimizing indicators that can increase persistence.

Thus it can be stated that self-determination affects the performance of the principal of SD Negeri in Aceh Besar District. In other words, the performance of the principal of SD Negeri in Aceh Besar District can be improved by optimizing their self-determination. Thus, this study's findings, which state that selfdetermination has a positive direct effect on elementary school principals' performance, are following the research results and the theory referred to in this study.

1. Organizational Culture Has a Positive Direct Effect on the Performance of the Principals of Public school. The sixth research finding: organizational culture has a positive direct effect on the performance of the head of public elementary schools, meaning that if the organizational culture is getting stronger, the performance of the principal of SD will also be more robust in the medium category, 43 people $(31.852 \%)$ in the low category, and 14 people $(10.370 \%)$ in the low category. Overall, it can conclude that the organizational culture of the head of SD Negeri in Aceh Besar District tends to be in the medium category.

Based on hypothesis testing with a path coefficient of $\rho 52=0.175$ and $t=2.184$ with a significance level of 0.031 (the hypothesis is accepted if the $t$ value $<0.050$ ) is received. It shows that the organization's culture can determine $32.1 \%$ of changes in the performance of primary school heads.

The study results concluded that organizational culture affects the performance of the principal of SD Negeri in Aceh Besar District. This study's results are in line with the theory proposed by Latham and Locke (2009: 79), which states that organizational culture directly affects one's performance. When the corporate culture is high, the person's account will be higher. The results obtained also support research conducted by Putra and I Gusti Ayu (2019: 118); Lolowang et al. (2019: 26); Nwakoby et al. (2019: 1213); and research by Syardiansah et al. (2020: 849) that organizational culture has a significant effect on performance. Thus it can be concluded that to improve the performance of the principal of SD Negeri can be done by optimizing the organizational culture. The corporate culture variables are on indicators: (a) individual initiative, (b) tolerance for risky actions, (c) support and direction from superiors, (d) control, (e) a transparent reward system, ( f) tolerance of conflict, and (g) good communication with supervisors and subordinates. The results of further calculations found that the indicators of support and direction from managers are dominant indicators in providing a correlation for improving organizational culture. Thus, we enhance a corporate culture by optimizing support and guidance from superiors.

2. Work Motivation Has a Positive Direct Effect on the Performance of the Principals of SD Negeri

Seventh research finding: work motivation has a positive direct effect on the performance of the principal of SD Negeri, meaning that if the work motivation is higher, the understanding of the principal of SD will also be better. The distribution of work motivation data shows 32 people $(23.704 \%)$ in the high category, 75 people $(55.556 \%)$ in the moderate category, 27 people $(20,000 \%)$ in the low class, and one person $(0.0741 \%)$ in the low sort. Overall, it can conclude that the work motivation of the head of SD Negeri in Aceh Besar District tends to be in the medium category. Shows that $33.6 \%$ of changes in primary school principals' performance can determine by work motivation.

The study results concluded that work motivation affects the performance of the principal of SD Negeri in Aceh Besar District. This study's results align with the theory proposed by Colquitt, LePine, and Wesson (2015: 34), Verasari \& Hamzah (2019a), (2019b) and Robbins and Coulter (2018: 138), which states that work motivation directly affects one's performance. The study results also confirm the theory stated by Mathis and Jackson (2016: 114), which states that work motivation can improve one's performance. If work motivation is high, the person's performance will be even higher. The results obtained also support research conducted by Elisabeth (2008: 88); Syafii et al. (2015: 1142); Kiruja and Elegwa (2013: 73); Ghaffari et al. (2017: 92); Ali et al. (2016: 297); and research by Lee and Robyn (2016: 162) that work motivation has a significant effect on performance. Thus it can be concluded that to improve the performance of the principal of SD Negeri can be done by optimizing work motivation. In this study, work motivation variables based on indicators: (a) dedication or self-development, (b) responsibility for completing tasks, (c) independence, (d) personal satisfaction, (e) self-confidence, (f) happy to work hard, (g) want good results, (h) do not feel satisfied quickly, and (i) the type and nature of work that is pleasant. Further calculations found that the indicator is happy to work hard as the dominant indicator in providing a correlation to increase work motivation. Thus, it can state that to increase work motivation, it can optimize being happy to work hard. The principal in carrying out his job when it finished is not quickly satisfied and whatever work his boss gives him, whether it is difficult or not, remains fun for him; what else has the principle of being happy with work that requires personal responsibility. Thus, this study's findings state that work motivation has a positive direct effect on 
elementary school principals' performance, following the research results and the theory referred to in this study. 3. Job Satisfaction Has a Positive Direct Effect on the Performance of the Principal of SD Negeri The eighth research finding: job satisfaction has a positive direct effect on the performance of the principal of SD Negeri, meaning that if the job satisfaction is high, the performance of the principal of SD will also be more robust. The distribution of job satisfaction data shows that 26 people $(19.259 \%)$ are in the high category, 75 people $(55.556 \%)$ are in the moderate category, 31 people $(22.963 \%)$ are in a low category, and three people $(2.222 \%)$ are in a low category. Overall, the job satisfaction of the head of SD Negeri in Aceh Besar District tends to be in the medium category. The hypothesis testing with the path coefficient, namely: $\rho 54$ equal to 0.245 and $t=3.072$ with a significance level of 0.003 (the hypothesis is accepted if the significance level of the count $<0.050$ ). It shows that $37.5 \%$ of primary school heads' performance can determine job satisfaction. The study results concluded that job satisfaction affects the performance of the principal of SD Negeri in Aceh Besar District. This study's results are in line with the theory proposed by Colquitt, LePine, and Wesson (2015: 34), which states that job satisfaction directly affects one's performance. The study results also confirm the theory stated by Robbins and Coulter (2018: 138) that job satisfaction can increase one's performance. When job satisfaction is high, the person's performance will be higher. The results obtained also support research conducted by Shaju M. and Subhashini (2017); Bakotić (2016: 118-130); and Al-Ajlouni (2015); Latif et al. (2013); and Saranya (2014) that job satisfaction has a significant effect on performance. Thus it can be concluded that to improve the performance of the principal of SD Negeri can be done by optimizing job satisfaction. In this study, job satisfaction variables are on indicators: (a) challenging work, (b) appropriate rewards, (c) supportive working conditions, (d) supportive colleagues, and (e) suitability for work. The results of further calculations found that the supportive co-worker indicator is the dominant indicator in providing a correlation to increase job satisfaction. Thus, it can state that improving job satisfaction can be done by optimizing supportive co-worker indicators.

Principals who are successful in carrying out their duties can realize their abilities and encourage themselves to carry out their duties. A principal cannot work effectively if it is not supported by understanding his duties and responsibilities. Thus, this study's findings state that job satisfaction has a positive direct effect on the performance of elementary school principals, according to the results of the research and the theory referred to in this study. Based on the results of hypothesis testing that accepted the eight proposed research hypotheses, it found that a Theoretical Model of SD principal's performance was the development of several theories, especially "Integrative Model of Organizational Behavior" from Colquitt, LePine, and Wesson; "An Organizational Behavioral System" from Newsroom; and Robbins and Judge's selfcommitment to performance and satisfaction model.

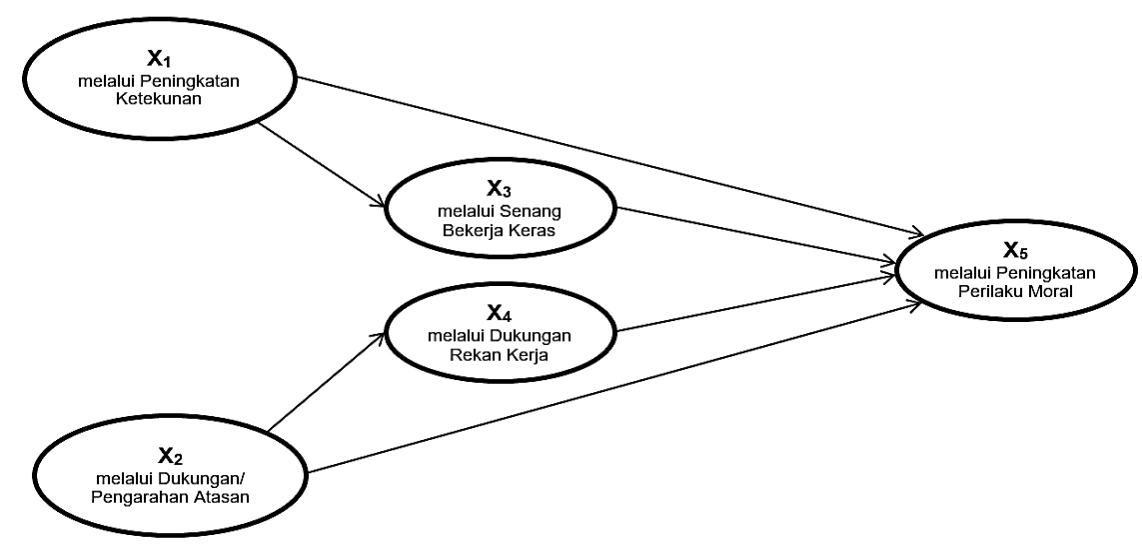

Figure 1. New Findings of research Paradigm

\section{Conclusion}

Based on the study results of obtained in this study are:

1. The proposed principal performance model's effectiveness is built additively through self-determination, organizational culture, work motivation, and job satisfaction in organizing quality schools. The efficiency of the efficiency in the performance model of the principal of SD Negeri in Aceh Besar District rests on the principal's ability to optimize his determination, optimize organizational culture in schools, increase work motivation and self-satisfaction when leading and directing teachers/staff at schools. This performance model also explains the SD principal's role as an inspiration, counselor, and supervisor to the entire school community in providing quality education in schools. 
2. There are direct and indirect effects between variables:

a. The positive direct effect of self-determination on the heads of public elementary schools' work motivation in Aceh Besar district.

b. The direct positive influence of organizational culture on the heads of public elementary schools' work motivation in Aceh Besar district.

c. The direct positive effect of self-determination on the job satisfaction of the head of SD Negeri in Aceh Besar District, d. The direct positive influence of organizational culture on job satisfaction of the head of public elementary schools in Aceh Besar district.

e. The direct positive influence of self-determination on the performance of the head of SD Negeri in Aceh Besar District, $f$. The direct positive influence of organizational culture on the head of SD Negeri in Aceh Besar District.

g. The positive direct effect of work motivation on the performance of the principal of SD Negeri in Aceh Besar District.

h. The positive direct effect of job satisfaction on the head of SD Negeri in Aceh Besar District,

i. The indirect effect of self-determination through work motivation on the performance of the principal of SD Negeri in Aceh Besar District.

j. The indirect influence of organizational culture through work motivation on the performance of the principal of SD Negeri in Aceh Besar District.

$\mathrm{k}$. The indirect effect of self-determination through job satisfaction on the performance of the pr. The indirect influence of organizational culture through job satisfaction on the performance of the head of SD Negeri in Aceh Besar District.

\section{Recommendations}

Based on the research results, several recommendations were put forward for various parties directly related to the principal's performance. To the Aceh Besar District Government, the Aceh Besar District Education Office should treat the post of SD head as an academic position so that the principal is a professional elementary school in every appointment. A school principal's readiness element must be on carrying out tasks, moral behavior, and opposing behavior in carrying out their responsibilities at school. For this reason, it is suggested to the Aceh Besar District Education Office to carry out both written and oral tests to see the ability of a prospective school principal before being appointed as a school principal. Special examinations are needed to see the principal's planning ability in determining the priority scale of school achievements according to the strengths and weaknesses of the school. To find excellent and competent school principals, researchers also suggested that the Aceh Besar District Education Office ask for assistance from competent educational institutions as partners in selecting prospective school principals. Some of the limitations of this study are suggested for researchers to conduct further research to find evidence that performance can influence other exogenous variables outside of self-determination, organizational culture, work motivation, and job satisfaction; which have an asymmetrical relationship with each other in order to obtain the dominant variables determining changes in the performance of primary school heads. It is necessary to increase the research sample, representing the principle of SD Negeri in Aceh Besar District so that the generalization coverage is more comprehensive by overcoming these limitations.

\section{Acknowledgement}

The authors would like to thanks to the people who have been instrumental in their assistance and the successful completion of this study.

\section{Author's Contributions}

All authors discussed the results and contributed to from the start to final manuscript.

\section{Conflict of Interest}

The authors declare that they have no competing interests.

\section{References}

Amstrong, M \& Baron, A. (2011). Performance Management: The New Realities, Institute of Personnel and Development, New York.

Atkinson, J. W. (2010). An Introduction to Motivation. Jossey-Bass

Coleman, M \& Derek, G. (2010). Educational Leadership and Management. New York: McGraw Hill. 
Colquitt, Jason A., Jeffery A. LePine, dan Michael J. Wesson. (2015). Organizational Behavior: Improving Performance and Commitment in the Workplace. New York: McGraw Hill.

Dale, T. (2012). Seri Manajemen Sumber Daya Manusia Kinerja, cetakan kelima, Jakarta : PT Elex Media Komputindo.

Fielder, B dan Chemers. (2005). Strategic Management for School Development Leading Your School's Improvement Strategy. London: Sage Publication Company.

Geert, H. (2006). Culture's Consequences, International Differences in Work - Related Values. London: Sage Publications.

George, M. J, Jones, Gareth, R. (2015). Contemporary Management. New York: McGraw-Hill.

Gibson. I, Donnelly, \& Konopaske. (2009). Organization. Behavior, Structure, Processes, Thirteen Edition. New York: Mc. Graw Hill Companies.

Griffin. (2016). Komitmen Organisasi,Terjemahan. Jakarta: Penerbit Erlangga.

Gunter, H. M. (2001). Leader and Leadership in Education. California: Paul Chapman Publishing.

Hoy, Weyne K. dan Cecil G. Miskel. (2005). Educational Administration. New York: McGraw Hill.

Hanjarini, G. D., Sugiarto, S., \& Karnati, N. (2020). The Effect of Job Design and Quality of Work Life on Affective Commitment of Vocational High School's Teachers in East Jakarta Indonesia. International Journal for Educational and Vocational Studies, 2(3).

Ivancevich, G., Donnelly, \& Konopaske. (2009). Organization. Behavior, Structure, Processes, Thirteen Edition. New York: Mc. Graw Hill Companies.

Kerlinger, F. N. (2015). Asas-Asas Penelitian Behavioral. Edisi Ketiga. Yogyakarta: Gadjah Mada University Press.

Kristiani, W., Matin, M., \& Sugiarto, S. (2019). The Effect of Organizational Culture and Perceived Organizational Support (POS) Towards Organizational Citizenship Behavior (OCB) Teacher SDK PENABUR Jakarta. International Journal for Educational and Vocational Studies, 1(6), 528-532.

Manaf, A., Matin, M., \& Zulaikha, S. (2019). Effect of Work Environment and Work Loads on the Performance of Police Educators in Sepolwan Lemdiklat Polri. International Journal for Educational and Vocational Studies, 1(5), 461-466.

Musifudin, M., Rugaiyah, R., Akbar, M., \& Suhardi, M. (2019). Knowledge of Management and Work Environment Principal of Madrasah Ibtidaiyah In Creating Service Quality In Islamic Boarding School. International Journal for Educational and Vocational Studies, 1(2), 100-103.

Rajindra, D., Karnati, N., \& Soefijanto, T. A. (2020). Influence of Motivation and Job Satisfaction on Teacher Creativity in SMA Negeri Region II Jakarta Barat. International Journal for Educational and Vocational Studies, 2(1).

Ridlo, M. R., Widodo, S. E., \& Elianasari, E. (2020). The Effect of Power and Motivation in Teacher Organizational Citizenship Behavior (OCB) at Madrasah Aliyah in Central Lombok District. International Journal for Educational and Vocational Studies, 2(2).

Siagian, F., \& Sirait, J. E. (2019). The Influence of Director Leadership on Improvement of Creativeness Education Manpower, Productivity of Employee Education and Learning Success Students in Cirebon Maritime Academy. International Journal for Educational and Vocational Studies, 1(6), 533-538.

Simorangkir, S. T., Karnati, N., \& Abdullah, T. (2019). The Effect of Supportive Leadership, Learning Culture, and Responsibility on Job Performance of Teacher in Junior High Schools of South Tangerang. International Journal for Educational and Vocational Studies, 1(2), 120-129.

Sugiyono. (2016). Metode Penelitian Pendidikan, Pendekatan Kuantitatif, Kualitatif, dan RED. Bandung: Alfabeta. Suharsaputra, Uhar. (2017). Administrasi Pendidikan. Bandung: Refika Aditama.

Verasari, M., \& Hamzah, H. (2019a). The Effect of Experienced Incivility From Supervisor and Coworkers Towards Instigated Incivility in Daily Level Among Nurses. International Journal for Educational and Vocational Studies, 1(4), 359-363.

Verasari, M., \& Hamzah, H. (2019b). Psychological Distress As A Mediator Variable Between Experienced Incivility From Supervisor And Coworker To Instigated Incivility. International Journal for Educational and Vocational Studies, 1(4), 368-372.

Wirawan. (2017). Manajemen Sumber Daya Manusia Indonesia. Jakarta: Raja grafindo.

Yukl, G. (2015). Kepemimpinan Dalam Organisasi (Edisi 7). Jakarta: Indek. 